\title{
Decision-making processes in Sylhet City Corporation: who plays the dominant role?
}

\section{Muhammad Mustofa Kamal}

Department of Public Administration

Shahjalal University of Science and Technology

Bangladesh

Email: mustofa-pad@ sust.edu mustafapadsust@gmail.com

\section{Anwara Begum}

Department of Public Administration

Shahjalal University of Science and Technology

Bangladesh

Email: anwara-pad@sust.edu anwara_begum@yahoo.com

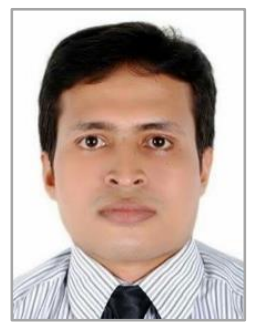

$$
\text { anwara_begum@yahoo.com }
$$

\section{Chowdhury Abdullah Al-Hossienie}

Department of Public Administration

Shahjalal University of Science and Technology

Bangladesh

Email: hossienie-pad@ sust.edu hossienie@yahoo.com
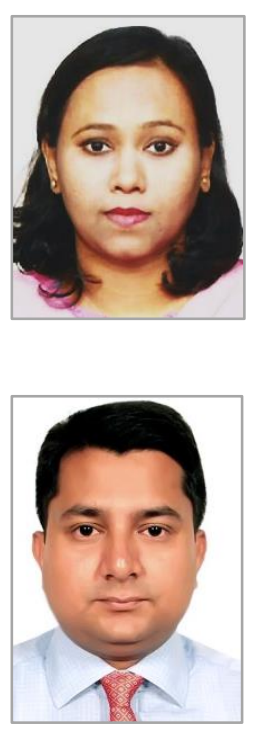

\begin{abstract}
A rational decision-making process is essential for municipal governments, as it promotes progressive development and makes them more democratic and service-oriented. This study explores the decisionmaking process in Bangladesh's Sylhet City Corporation (SCC). Both primary data via a survey of relevant respondents and secondary data were collected. The study found that, although both the mayor and councillors participate in making decisions at the SCC, it is the mayor who plays the dominant and vital role, exercising power by convincing councillors of his leadership qualities. For these reasons, the decision-making process of the SCC is not fully democratic. If councillors were able to play a greater role, the decisions of the SCC would be more collective.
\end{abstract}

Keywords: Decision-making, urban local government, city corporation, mayor, councillor

DOI: https://doi.org/10.5130/cjlg.v0i20.6468

Article History: Received 18/05/16; Accepted 23/02/18; Published 13/03/2019

Citation: Commonwealth Journal of Local Governance 2017, 20: 6468, - https://doi.org/10.5130/cjlg.v0i20.6468

(C) 2019 Muhammad Mustofa Kamal, Anwara Begum and Chowdhury Abdullah Al-Hossienie. This is an Open Access article distributed under the terms of the Creative Commons Attribution 4.0 Unported (CC BY 4.0) License (https://creativecommons.org/licenses/by/4.0/), allowing third parties to copy and redistribute the material in any medium or format and to remix, transform, and build upon the material for any purpose, even commercially, provided the original work is properly cited and states its license. 


\section{Introduction}

As with most democracies, local government plays an important role in the development of Bangladesh. Over 250 years ago Jean-Jacques Rousseau identified local government as the training ground for democratic culture, and Alexis de Tocqueville during his 1830s visit to the USA noted the importance of local citizens and local governments in keeping democracy in that country afloat (UN 1996). Local government is thus usually viewed as the basis of national government (Khan 2009).

In Bangladesh, rapid population growth, coupled with the limited availability of agricultural land, has resulted in a steady shift of population from rural to urban areas (Siddiqui 2005). City corporations, which form the most important tier of urban local government, have therefore assumed considerable importance. They are responsible for various development activities and service provision for citizens, and are tasked to ensure good governance in administration and to exercise democracy in all their activities. However, there are several problems in the functioning of city corporations. Among these the most substantial one is the decision-making process.

This study explores the approach to decision-making in Sylhet City Corporation (SCC). In theory, the general public's participation is important, and citizens can submit proposals identifying problems at the meetings of the city corporation. Unfortunately, however, in practice the participation of both local people and local councillors (elected at ward level ${ }^{1}$ ) appears to be often ignored in SCC decision-making processes.

Good practice suggests that, for development to progress, a rational and transparent decision-making process is essential. Although some studies have been conducted on city corporations, there is limited work on their decision-making processes, so this study is highly relevant. It examines who are the dominant players in the decision-making process at SCC, in an attempt to analyse problems and propose strategies to address them. The study draws on structured interviews with the mayor, councillors, officials and members of the general public, and a review of SCC documents.

\section{Literature review}

Bangladesh inherited a colonial local government structure, first under the British Raj for about 200 years and then under Pakistan for about 24 years (Panday 2011). Local government was established at independence in 1971, with different rural and urban local government structures. In rural areas, three tiers of local government legally exist: union parishad, upazila parishad and zila parishad. In urban areas, meanwhile, there are two distinct categories of local government body: pourashavas (municipalities) in small towns and city corporations in large cities (Ahmed and Panday 2013).

The first municipal corporation was set up in Madras in 1687, and in Bengal the Dhaka pourashava was established in 1864. Under Pakistan's rule, the 1960 Municipal Administration Ordinance

\footnotetext{
${ }^{1} \mathrm{~A}$ ward is a local government subdivision.
} 
brought the municipalities in line with basic principles of democracy (Rahman 1988). After independence, the legal basis of local government, and its democratic basis, was established in Articles 59 and 60 of the 1972 Constitution, with a number of later amendments. At present, there are 320 pourashavas and 12 city corporations in Bangladesh.

The mayor and the councillors of a city corporation are directly elected, and one-third of the total number of councillor seats are reserved for women (Government of Bangladesh (GoB) 2009), although women representatives rarely participate strongly in decision-making, due to the domination of their male counterparts. Gender discrimination remains prevalent in Bangladesh (Begum 2007). The reserved seats for women in local government bodies are aimed at securing their active involvement and support in socio-economic development (Prasad 2014). Reserved seats are an imperative, as in the normal process women are: "reluctant to contest elections because of both the murkiness and the violence that often characterise electoral politics" (Prasad 2014, p. 431). Sometimes there are allegations of irregularities, including ballot papers being seized or force being used to cast votes, creating chaos in polling stations at city corporation elections in Bangladesh (The Daily Star 2018). One of the election officials after a recently held city corporation poll stated: "Voting was suspended [at some polling centres] over allegations of ballot stuffing, attempts to occupy the centres and clashes between supporters of rival candidates" (Mamun et al. 2018). In a male-dominated society women's voices also tend to get drowned out in the din created by men (Prasad 2014). Furthermore, women councillors sometimes face gender-based harassment and discrimination from the public, colleagues, the police and other government officials.

During its two and a half year tenure, a city corporation will form standing committees in a number of different areas including finance and establishment of the city corporation; waste management; education, health and family planning; city planning and development; audit and accounts; city infrastructure, construction and conservation; water and electricity; social welfare and community centres; environmental development; sports and culture; birth-death registrations; communication; market price observations, monitoring and evaluation; and disaster management (GoB 2009). The chairmen and members of the standing committees of the city corporation are elected from the councillors. A standing committee may be formed for a specific issue, excluding the above mentioned areas, on the basis of decisions taken by the corporation. According to the Local Government (City Corporation) Act 2009, the recommendations of the standing committees would be considered at the following general meeting of the corporation (GoB 2009).

In an overview study of council structures in 14 countries, Mouritzen and Svara (2002) found wide divergences. Some countries had strong executive committees within the city councils, while other countries had no executive committees at all. "In some countries, standing committees had decisionmaking powers, in other countries they played an advisory role only, and in others standing 
committees were not necessarily used" (Mouritzen and Svara 2002, p. 50). Among the 14 countries, they found Ireland to be at one extreme: council meetings are rare and tend to focus on general policies, and councils have neither an executive committee nor empowered standing committees. At the other extreme, Sweden had councils with an executive committee that worked closely with the $\mathrm{CEO}$, and standing committees that were heavily engaged in the day-to-day execution of policies (Mouritzen and Svara 2002). Good governance and decision-making are directly interrelated. According to the United Nations Economic and Social Commission for Asia and the Pacific (UNESCAP), good governance embodies processes that are participatory, consensus-oriented, accountable, transparent, responsive, effective and efficient, equitable and inclusive, and which follow the rule of law (UNESCAP 2009). Decision-making involves choice between alternative plans of action, which in turn involves facts and values, and every decision consists of a logical combination of fact and value propositions (Robbins 2005). Good governance can be ensured by strengthening local government bodies so local people can strongly participate in local-level decision-making as well as development activities. In addition, civil society, pressure groups or non-governmental organisations (NGOs) can play a constructive role in ensuring good governance (Hye 2000). Civil society acts as a buffer between the state and citizens to protect the public interest (Khan 2009). Participation by both men and women is a cornerstone of good governance. Participation may be direct or through legitimate representatives (UNESCAP 2009).

In Bangladesh, however, there is no uniform authority in urban areas for planning and implementing development activities. Challenges at the city corporation level may include service delivery problems, financial and administrative problems, and regulatory problems, including the absence of appropriate regulations, inappropriate amendments and regulatory interventions (Ahmed 2003). In a case study of Rajshahi City Corporation (RCC), Panday (2007) analysed the role of intraorganisational coordination in implementing infrastructure policy. He found that lack of coordination led to many problems, such as failure to meet project deadlines, overlap and duplication of activities (Panday 2007). Another key problem was the discrepancy between form and reality in the RCC's policymaking. Although policies were supposed to be designed and implemented democratically, the mayor was the supreme authority in every aspect of the city corporation, maintaining a patron-client relationship with councillors, and without his approval project implementation was unfeasible (Panday and Jamil 2010).

Local government in Bangladesh also faces additional challenges of bureaucratic dominance; absence of well-established democratic values; and abuse of power and misuse of government resources by building nexus among ruling party members, local government officials and the local elite (Panday 2011; Chowdhury and Aktaruzzaman 2016; Asaduzzaman 2009). Furthermore, through control of funding, central government interferes in almost every aspect of local government, which is thus often 
reduced to a rubber-stamp body (Khan 1997 cited in UNESCAP 2002). Development partners also place conditions on grants and loans, which weaken the autonomous power of city corporations.

\section{Methodology}

This study uses a combination of qualitative and quantitative methods.

Sylhet City Corporation (SCC) was selected as the area of the study. Located in north-eastern Bangladesh, it was promoted from a municipal corporation to a city corporation in 2001 . The city has 27 wards and 210 mohallas (sub-wards) with a total area of $26.50 \mathrm{~km}^{2}$.

Primary data was collected from the mayor, councillors and officials who participate in the decisionmaking process of the SCC, as well as other stakeholders, using a structured interview schedule with both closed and open questions. Interview schedules were piloted before the full data collection. Secondary data was collected from published books, journals, articles, periodicals, newspapers, the internet and relevant organisations.

In this study, elected representatives, officials and stakeholders of SCC make up the sample population. All voters within the SCC have been considered as stakeholders. Data was collected from 120 individuals: the mayor, 34 elected councillors, 14 SCC officials with decision-making authority, 7 representatives of other government offices who are sometimes invited to general meetings of the SCC, and 64 stakeholders.

\section{Findings and discussion}

\section{Analysis of the collected data}

The purpose of the data collection was to establish the decision-making process of the SCC. Of the 56 SCC representatives and officials interviewed, $82 \%$ were male and $18 \%$ female. Among the stakeholder respondents (general public), $69 \%$ were male and $31 \%$ female.

The SCC representatives and officials comprised: 1 mayor, 25 councillors (general seats), 9 women councillors (reserved seats), 14 officials who attended SCC general meetings to participate in decision-making, and 7 other officials representing various government departments within the territory and jurisdiction of the SCC (Table 1).

Table 1: Roles of respondents (representatives and officials)

\begin{tabular}{|l|c|c|}
\hline & Number & Percentage (\%) \\
\hline Mayor & 1 & 2 \\
\hline Councillor (general seat) & 25 & 45 \\
\hline Woman councillor (reserved seat) & 9 & 16 \\
\hline SCC official & 14 & 25 \\
\hline Representative of other government office & 7 & 13 \\
\hline Total & 56 & 100 \\
\hline
\end{tabular}


When a problem occurs in a ward of the SCC, local people along with the local councillor identify the problem. The councillor then reports it directly to the mayor or the SCC general meeting. After the SCC meeting the mayor assigns the matter to the relevant SCC standing committee in order to develop and analyse alternative courses of action.

According to the Local Government (City Corporation) Act 2009, all SCC decisions are made at general meetings of the council. Under the Act, the city corporation must hold such a meeting at least once a month on a working day of the first week. These meetings are presided over by the mayor, and if $50 \%$ of councillors request in writing that the mayor call a meeting, he is bound to do so. A quorum of one-third of all councillors is required to transact any business.

Interviewees were asked where they thought SCC decisions were made and they were allowed to choose multiple responses from several options. Among representatives and officials, almost all (96\%) said decisions were taken in monthly general meetings, although a few (4\%) thought that sometimes decisions are taken by the mayor alone as well as at monthly general meetings of the city corporation (Table 2). Among the general public respondents, 97\% thought decisions were taken in monthly meetings of the city corporation, $1 \%$ thought they were imposed by central government, and the remaining $1 \%$ believed decisions were taken by the mayor alone (Table 3 ).

Table 2: Opinions on locus of decision-making (representatives and officials)

\begin{tabular}{|l|c|c|}
\hline & Number & Percentage (\%) \\
\hline Monthly general meeting of the city corporation & 54 & 96 \\
\hline $\begin{array}{l}\text { Monthly general meeting of the city corporation, } \\
\text { as well as sometimes taken by mayor alone } \\
\text { using his legitimate administrative authority }\end{array}$ & 2 & 4 \\
\hline Total & 56 & 100 \\
\hline
\end{tabular}

Table 3: Opinions on locus of decision-making (general public)

\begin{tabular}{|l|c|c|}
\hline & Number & Percentage (\%) \\
\hline Monthly general meeting of the city corporation & 62 & 97 \\
\hline Imposed by central government & 1 & 1 \\
\hline Taken by mayor alone & 1 & 1 \\
\hline Total & 64 & 100 \\
\hline
\end{tabular}

One of the councillors stated:

Most of the decisions of the SCC are taken by mayor alone and sometimes decisions are taken by officials through file processing. But any major decision has to be taken in the general meeting of the SCC (Interview 17).

Some councillors stated that the mayor controls power in the SCC. Another councillor said:

General meetings of the SCC are not regularly held and most of the times these meetings are called on less important issues (Interview 9). 
The present study found various standing committees to exist in the SCC. After reviewing and scrutinising a problem, standing committees develop and analyse possible courses of action and make recommendations which are placed on the agenda of SCC general meetings, allowing all councillors and the mayor to participate in discussion. In the study it was found that decisions were taken on the basis of consensus, with the mayor and councillors choosing the best alternative after detailed fruitful discussion.

The Local Government (City Corporation) Act 2009 provides that decisions of city corporations are subject to a majority vote in favour of those present at the general meeting. The mayor has a casting vote if necessary. However, in Panday and Jamil's study of RCC (2010) the authors found that, in practice, decision-making was dominated by the mayor, as the mayor's preferences were usually approved at the general meeting. They further found that RCC's standing committees were not effective. In the present study, one councillor commented:

Though there exist various standing committees in the SCC, the recommendations of the committees are not brought to the meeting as agenda [items]. As a result, members of the standing committees lost interest in participating in [the] decision-making process, and [the] agenda of the meeting is set for less important issues (Interview 15).

This study also asked interviewees which people were responsible for decision-making in SCC and they were allowed to choose multiple responses from several options such as mayor, councillors and officials. Almost all respondents (96\%) who were representatives and officials chose all the three options i.e. mayor, councillors and officials and mentioned that all of them participated in decisionmaking, with just $4 \%$ claiming that only the mayor and councillors made the decisions, while officials assisted in implementing the decisions (Table 4). Among the general public respondents, $31 \%$ thought it was the mayor and councillors, while $69 \%$ thought it was the mayor, councillors and officials together take the decisions of SCC (Table 5).

Table 4: Views on who participates in decision-making (representatives and officials)

\begin{tabular}{|l|c|c|}
\hline & Number & Percentage (\%) \\
\hline Mayor, councillors and officials & 54 & 96 \\
\hline Mayor and councillors & 2 & 4 \\
\hline Total & 56 & 100 \\
\hline
\end{tabular}

Table 5: Views on who participates in decision-making (general public)

\begin{tabular}{|l|c|c|}
\hline & Number & Percentage (\%) \\
\hline Mayor and councillors & 20 & 31 \\
\hline Mayor, councillors and officials & 44 & 69 \\
\hline Total & 64 & 100 \\
\hline
\end{tabular}

Panday and Jamil (2010) found that the participation of the women councillors from reserved seats in decision-making processes was minimal. Another study in Bangladesh echoed this, and listed a number of significant reasons: a huge workload and vast jurisdiction (as female representatives from 
reserved seats cover three wards, whereas representatives of general seats cover just one ward), harassment by male counterparts (including sexual harassment), inappropriate behaviour, verbal abuse by male counterparts, physical aggression, exclusion from development activities and the decisionmaking process, and coercion over decision-making. These can be seen as symptoms of a patriarchal society, where people are more comfortable working with men than women (Rupa and Karim 2011). On a positive note, however, in this study, one woman councillor stated:

Because of the discriminatory functions mentioned in the City Corporation Act, women councillors (reserved) cannot strongly participate in every decision. But [the] mayor of the SCC gives us opportunity, as given to [a] councillor from general seat. In every meeting he invites us to participate. If any funds come from central government, he distributes the fund equally among all councillors (general and reserved). In every standing committee, there [is a] presence of women councillors. There is also one Panel Mayor [drawn] from women councillors (Interview 27).

According to Mouritzen and Svara (2002), there are four generic forms of city council governance: 'strong mayor', 'committee leader', 'collective' and 'council manager'. Their study found that the strong mayor form exists in France, Spain, Italy, Portugal etc. In this form, the mayor is a dominant figure in the city council and here, "the elected mayor controls the majority of the city council and is legally and actually in full charge of all executive functions. The CEO serves at the mayor's will and can be hired and fired without the consent of any other politicians or political bodies" (Mouritzen and Svara 2002, p. 55). They found that the committee leader form exists in Denmark, Sweden and Great Britain; in this type of governmental form, standing committees are composed of elected politicians. Here "one person is clearly 'the political leader' of the municipality - with or without the title of mayor. [The] mayor may or may not control the council and executive powers are shared" (Mouritzen and Svara 2002, p. 56). The collective form prevails in Belgium and the Netherlands, where:

The decision centre is one collegiate body, the executive committee that is responsible for all executive functions. The executive committee consists of locally elected politicians and the mayor who presides. In this form, greater emphasis is given to the laymen principle and political leadership and professionalism are accommodated to it (Mouritzen and Svara 2002, p. 56).

Mouritzen and Svara further concluded that the council manager form prevails in the United States, Australia, Ireland, Finland, and Norway. In this form:

all executive functions are in the hands of a professional administrator - the city manager - who is appointed by the city council, which has general authority over policy but is restricted from involvement in administrative matters. The council is relatively a small body, headed by a mayor who formally has presiding and ceremonial functions only (Mouritzen and Svara 2002, p. 56).

Within these forms, researchers (Mouritzen and Svara 2002; Haus and Sweeting 2006 and Shalom 2015) suggest a number of possible approaches to, or models of leadership in local government. Mouritzen and Svara (2002) cited in Shalom (2015) identified three types of leadership approaches 
which are layman rule, managerial/professional rule and political rule. "Under layman rule, elected members of the community are actively and effectively involved in decision-making. Under professional rule, because politicians (including full-time mayors) may lack expertise and professional knowledge in administrative and governmental issues, they depend on the advice of experts" (Mouritzen and Svara 2002 cited in Shalom 2015, p. 5). "Managerial leadership is based on on-going administration" (Haus and Sweeting 2006 cited in Shalom 2015, p. 5). Under political rule, political leadership mobilises administration to fulfil its political objectives in a democratic system (Haus and Sweeting 2006). Policymaking, decision-making, budget allocation and other core functions of the local government are initiated by political authority under political rule (Mouritzen and Svara 2002 cited in Shalom 2015). Shalom (2015) identified a fourth approach of strategic leadership, which deals with long-term strategic issues, irrespective of re-election issues in the future of the organisation where the leader of the organisation is guided by a vision and takes strategic decisions. Shalom (2015) believed that the local government authority with a combination of the four kinds of leadership models - layman, managerial, political and strategic - would be considered as a strong local authority in case of decision-making processes.

The present study found that about three-quarters of respondents from the representatives and officials group said decisions of the SCC were taken collectively, whereas the rest said that decisions were taken individually by the mayor (Table 6). On the other hand, among the general public respondents, only 58\% said they knew how SCC decisions were taken, while the rest did not know (Table 7). Among this $58 \%$ of general public respondents, Table 8 shows the breakdown of different decisionmaking mechanisms that are believed to be used in the SCC.

Table 6: Views on how SCC decisions are made (representatives and officials)

\begin{tabular}{|l|c|c|}
\hline & Number of respondents & Percentage (\%) \\
\hline Individually by mayor & 15 & 26.8 \\
\hline Collectively & 41 & 73.2 \\
\hline Total & 56 & 100.0 \\
\hline
\end{tabular}

Table 7: Awareness of how SCC decisions are made (general public)

\begin{tabular}{|l|c|c|}
\hline & Number of respondents & Percentage (\%) \\
\hline Yes & 37 & 57.8 \\
\hline No & 27 & 42.2 \\
\hline Total & 64 & 100.0 \\
\hline
\end{tabular}

Table 8: Views on how SCC decisions are made (general public)

\begin{tabular}{|l|c|c|}
\hline & Number of respondents & Percentage (\%) \\
\hline Individually by mayor & 3 & 8.1 \\
\hline Collectively & 27 & 73.0 \\
\hline On voting & 7 & 18.1 \\
\hline Total & 37 & 100.0 \\
\hline
\end{tabular}


One councillor said:

There is no record of voting in taking decisions of the SCC. All decisions are taken on consensus. If a single councillor opposes a decision, it is not passed in the meeting (Interview 18).

The findings of this study suggest that decisions made at the SCC are neither completely rational nor completely irrational. Rather, they end up with satisficing.

Moreover, the following rather divergent view was typical:

Though decisions are taken collectively at the meeting of the city corporation, the actual scenario is completely different. Here the supreme decision-maker is [the] mayor who is able to handle the matter using his own leadership quality and creates such environment in the general meeting of the SCC that no councillor can alienate his proposal. (Interview 30).

Using the categorisation of Mouritzen and Svara (2002), it can be concluded that the 'strong mayor' form prevails in the SCC. This echoes findings by Panday and Jamil (2010) in the RCC where, although it was claimed decision-making was based purely on democratic principles, in actual practice the process was dominated by the mayor and his close associates.

This type of situation may be termed 'patrimonialism', i.e. the rule of preference of one or several actors rather than any formal decision-making procedure. In the case of the SCC, it is a one-man show where the mayor is the decisive actor in most cases. His consent is crucial for the positive outcome of a decision, and his approval is even required before an issue can get on the agenda. In this study, more than half of the respondents in the representatives and officials group, and three-quarters of the general public group, believed that the mayor, not councillors, was the vital role player in decisionmaking (Tables 9 and 10).

Table 9: Views on who is the vital role player in decision-making (representatives and officials)

\begin{tabular}{|l|c|c|}
\hline & Number of respondents & Percentage (\%) \\
\hline Mayor & 33 & 58.9 \\
\hline Councillors & 23 & 41.1 \\
\hline Total & 56 & 100.0 \\
\hline
\end{tabular}

Table 10: Views on who is the vital role player in decision-making (general public)

\begin{tabular}{|l|c|c|}
\hline & Number of respondents & Percentage (\%) \\
\hline Mayor & 50 & 78.1 \\
\hline Councillors & 14 & 21.9 \\
\hline Total & 64 & 100.0 \\
\hline
\end{tabular}

However, the position is not clear-cut. For example, one councillor with a general seat noted:

A few days ago [the] mayor wanted to donate a piece of land to the Lions Club, responding to the application of the club members, but councillors strongly opposed the decision and at last the decision had to be annulled (Interview 25). 
It would appear, therefore, that this study only partially supports the work of Panday and Jamil (2010). In the SCC, the mayor plays a dominant role in the decision-making process, but does need the consent of all councillors - whereas in the case of the RCC, the council appears to be a one-man show.

\section{Concluding remarks and strategies proposed}

This study identified various problems in the decision-making process of the SCC. To overcome these problems, the most useful strategy would be to reduce the dominance of the mayor and empower councillors, so the SCC avoids merely 'rubber-stamping' decisions. One way to achieve this would be to change the present 'presidential' system of electing mayors. The presidential system means that a popularly elected mayor generally does not feel the need to bother about the views of councillors if they disagree with him. A better approach would be a 'parliamentary' system, in which the mayor is elected from among the councillors; so if the post holder becomes autocratic, councillors are in a better position to withdraw their support. The authors believe that this system would compel the mayor to ensure effective participation of councillors in decision-making processes.

Local government is a grassroots institution, and the exercise of democracy starts from the grassroots level. If a democratic environment does not prevail in the city corporation, it will tend to be an ineffective body.

The authors therefore recommend that the policymakers of Bangladesh should implement these changes, which will lead to ensure more democratic and people-oriented city corporations, which in turn will strengthen the foundations of democracy of Bangladesh.

\section{Declaration of conflicting interest}

The authors declared no potential conflicts of interest with respect to the research, authorship, and/or publication of this article.

\section{Funding}

The authors received no financial support for the research, authorship, and/or publication of this article.

\section{References}

Ahmed, M.U. (2003) Urban local government services in Bangladesh: Study on the regulatory problems. Available at: http://mapbangla.com/mapadmin/publications/15Local\%20Government\%20Services\%20_Published\%20 in\%20the\%20Journal\%20of\%20NILG.pdf [Accessed 10 December 2015].

Ahmed, T. and Panday, P.K. (2013) Local government in Bangladesh: Issues and challenges. Presented in a Seminar at the Department of Public Administration, Shahjalal University of Science and Technology, Bangladesh.

Asaduzzaman, M. (2009) Development role of the local governance institutions in Bangladesh: Empirical overview. Nepalese Journal of Public Policy and Governance, 24 (1), 117-132. 
Begum, A. (2007) Local governance in Bangladesh: Towards a 'critical mass' to combat discrimination against women with special reference to India. Available at:

http://unpan1.un.org/intradoc/groups/public/documents/apcity/unpan038194.pdf [Accessed 10 December 2015].

Chowdhury, M.S. and Aktaruzzaman, M. (2016) Citizen participation in urban local government: a case study of Kanaighat Paurashava in Bangladesh. Commonwealth Journal of Local Governance, 19, 119-134. doi: https://doi.org/10.5130/cjlg.v0i19.5451

Government of Bangladesh. (GoB) (2009) The Local Government (City Corporation) Act 2009 (Additional gazette of October 15, 2009) Government of the People's Republic of Bangladesh. Dhaka: Bangladesh Government Press.

Haus, M. and Sweeting, D. (2006) Local democracy and political leadership: Drawing a map. Political Studies, 54 (2), 267-288. https://doi.org/10.1111/j.1467-9248.2006.00605.x

Hye, H.A. (2000) Good governance: A social contract for the new millennium. In: Hye, H.A. (ed.) Governance, South Asian perspective (pp. 1-32). Dhaka: The University Press Limited.

Khan, M.M. (2009) Decentralization in Bangladesh: Myth or reality? Dhaka: Development Publishing House.

Mamun, S., Akand, R.I. and Hasnat, M.A. (2018) Six issues that marked Gazipur city polls. The Dhaka Tribune 27 June 2018 (Daily English News Paper of Bangladesh). Available at: https://www.dhakatribune.com/bangladesh/2018/06/27/six-issues-that-marked-gazipur-city-polls [Accessed 30 July 2018].

Mouritzen, P.E. and Svara, J.H (2002) Leadership at the apex: Politicians and administrators in Western local government. Pittsburgh: University of Pittsburgh Press, Digital Editions.

Panday, P.K. (2007) Policy implementation in urban Bangladesh: Role of intra-organizational coordination. Public Organization Review, 7 (3), 237-259. Available at: http://dx.doi.org/10.1007/s11115-007-00343. [Accessed 15 January 2014]. https://doi.org/10.1007/s11115-007-0034-3

Panday, P.K. (2011) Local government system in Bangladesh: How far is it decentralized? Lexlocalis: Journal of Local Self-Government, 9 (3), 205-230. https://doi.org/10.4335/9.3.205-230(2011)

Panday, P.K. and Jamil, I. (2010) Challenges of coordination in implementing urban policy: The Bangladesh experience. Public Organization Review, 11 (2), 155-176. https://doi.org/10.1007/s11115-010-0116-5

Prasad, D.R. (2014) Women empowerment in urban governance in India. Indian Journal of Public Administration, 60 (3), 426-442. https://doi.org/10.1177/0019556120140305

Rahman, M.M. (1988) Local self-government in Bangladesh. Rajshahi: University of Rajshahi, Bangladesh.

Robbins, S.P. (2005) Organizational behaviour. New Jersey: Pearson Prentice Hall.

Rupa, N.B. and Karim, M.R. (2011) Female representatives in local government system of Bangladesh: Role and reality. Lok Proshason Samoeeky, 50, 55-74.

Shalom, D. (2015) Local leadership and decision-making: Strengths and weaknesses of the local government leaders (Israeli cities). Available at: http://www.onshalom.com/wp-content/uploads/2011/04/LocalLeadership-and-Decision-Making.pdf [Accessed 24 August 2017].

Siddiqui, K. (2005) Local government in Bangladesh. Dhaka: The University Press Limited.

The Daily Star. (2018) AL's Jahangir Alam elected Gazipur mayor. The Daily Star 27 June 2018 (Daily English News Paper of Bangladesh). Available at: https://www.thedailystar.net/politics/gazipur-city-corporationpolls-2018-awami-league-mayor-runner-ahead-vote-counting-on-bangladesh-bd-1595608 [Accessed 30 July 2018].

UN. (1996) Local governance: Report of the United Nations Global Forum on Innovative Policy and Practices in Local Governance. New York: United Nations.

UNESCAP (2002) State of women in urban local government, Bangladesh. Bangladesh Report. The United Nations Economic and Social Commission for the Asia and Pacific (UNESCAP). Available at: http://www.capwip.org/readingroom/bangladesh.pdf [Accessed 18 September 2018].

UNESCAP (2009) What is good governance? The United Nations Economic and Social Commission for the Asia and Pacific (UNESCAP). Available at: https://www.unescap.org/resources/what-good-governance [Accessed 15 December 2015]. 